\title{
Use of local bioresources for post-harvest management of white rot of apple caused by Botryosphaeria dothidea
}

\author{
Kishor Sharma* and Harender Raj \\ (H. P.), INDIA \\ *Corresponding author. E-mail: ks414173@gmail.com \\ Received: November 23, 2017; Revised received: January 2, 2018; Accepted: February 25, 2018
}

Department of Plant Pathology, Dr. Y. S. Parmar University of Horticulture and Forestry, Nauni, Solan-173230

\begin{abstract}
Post-harvest fungal pathogens are reported to cause 10 to 25 percent losses in apple. Among various pathogens, white rot caused by Botryosphaeria dothidea is one of the important post-harvest diseases. Incidence of white rot was recorded between3.0-14.1 percent in important marketing yards of Himachal Pradesh. Golden Delicious variety of apple has been found to be most susceptible to white rot pathogen. Two botanical formulations by mixing equal quantity of leaves of Karu (Roylea elegans), Artemisia (Artemisia roxburghiana), Neem (Azadirachta indica), Bana (Vitex negundo), Tulsi (Ocimum sanctum) and seeds of Darek (Melia azedarach) made in water and cowurine were evaluated against the white rot pathogen. Fruit dip for 30 minutes in cow urine based formulation did not allowed the disease development to form lesions in artificially inoculated apple fruits. Also, fruits dipped in cow urine based formulation followed by their storage in card board boxes at room temperature $\left(25 \pm 3^{\circ} \mathrm{C}\right)$ for 30 days storage had minimum incidence $(2.8 \%)$ of white rot disease. Therefore, dip treatment of apple fruits with different bio -resources including water and cow urine based botanical formulation separately proved effective in the management of white rot (Botryosphaeria dothidea) of apple.
\end{abstract}

Keywords: Apple, Botanicals, Botryosphaeria dothidea, Lesion size, White rot

\section{INTRODUCTION}

Apple (Malus $\times$ domestica Borkh.) is one of the most important fruit crop grown all over the world. It is predominantly grown in the states of Himachal Pradesh, Jammu and Kashmir and Uttrakhand. In India, apple is grown in an area of about 3.13 lakh hectare with total annual production of 24.98 lakh metric tonnes. Productivity of apple is around $10 \mathrm{MT} / \mathrm{ha}$ in India in comparison to leading apple producing countries like Italy (42.4 MT/ha), Chile (33.3 MT/ha), France (44.3 MT/ ha) and the average world productivity is about 15.87 MT/ha (Anonymous, 2013). There are many other reasons for low apple productivity and among this damage caused by diseases are one of the dominant factor. Among fruits, post-harvest diseases occurred after harvest due to continuous malfunction caused by infection of different parasitic microbes. Therefore, post-harvest disease of apple fruit resulted in huge economic losses. Post-harvest losses in fruits to varied extent have been reported from different parts of the world. In United States, Anderson (1956) observed post-harvest loss due to diseases in apple fruit is about 80 to 90 percent. Despite modern storage facilities, apple suffers 5 to 25 percent losses due to fungal rots and other physiological disorders (Jijakli and Lepoivre, 2004).McCollum (2002) reported that fruit rot caused by fungal patho- gens can lead to considerable post-harvest losses varying with cultivar, area of production and season. Rosenberger (1997) estimated loss of 4.4 million dollar per year caused by post-harvest decay of apple in USA. In Northern Croatia, (Ivic et al., 2012) found that the average estimated apple rot loss during storage was 14.1 to $33.1 €$ in May, August, September and October in year 2004,2007, 2008 and 2009, respectively. Postharvest losses caused serious dents in the fruits industry of India as the average losses are to the tune of 30 percent of the total yield which are valued approximately 2 trillion rupees annually.

The most aggressive post-harvest fungal pathogens namely Penicillium expansum, Botrytis cinerea, Monilinia sp., Mucor piriformis, Rhizopus sp., Gloeosporium album and Alternaria sp. are present in those production areas where the most advanced technologies for storage are available (Eckert and Ogawa, 1988, Ilyas et al., 2007).In Himachal Pradesh, nearly about 21 pathogens reported to cause post-harvest fungal rot and decays in apple fruit (Kaul, 1979).Among different fungal post-harvest rots in apple, white rot caused by Botryosphaeria dothidea is one of important disease which also caused canker on the stems. Fruit rot and canker of apple caused by Botryosphaeria mali was first time reported from South Africa (Putterill,1919).Later, white rot was also observed as a 
major pre-harvest and post-harvest problem of apple in warm and wet weather conditions during summer (Fulkerson, 1960). Other workers have also been reported perennial cankers on the stem and rot on apple fruit in the field and during storage (Biggs and Miller, 2003). However, qualitative loss in apple production can have a negative impact on different parameters like consumer acceptability, nutrient status of fruit and financial income to producers. Pests, microbial infection mostly cause Post-harvest losses and quality deterioration of horticultural crops including apple, natural ripening processes and environmental conditions such as heat, drought and improper post-harvest handling (Onyeani et al., 2012; Kasso and Bekele, 2016).

However, a large number of fungicides have been reported to be effective against this particular pathogen (B. dothidea) worldwide, but intermittent and faulty use of distinct chemicals over the years has led to the development of environmental contamination and health hazards (Okigbo and Ogbomaya, 2006). Moreover, bio-chemicals derived from extracts of the plants or other bio-resources have no noxious impact and their use is wining wide acceptance among people as alternatives to the prevalent chemical control measures. Plants like Azadirachta indica, Ocimum sanctum, Eucalyptus spp, Aloe barbadensis, Vitex negundo etc. contain different secondary substances like phenols, flavonoids, quinones, tannins, saponins and sterol which can be utilized for their specific antifungal activities. However, cow urine is also capable of treating many curable as well as incurable diseases of human are caused by different clinical pathogens. For these reasons, it is necessary to develop new and effective control methodologies that are safe and show an insignificant risk to consumer health and environment. Hence, keeping all these points in view, the present study was undertaken with evaluation of the efficacy of locally available bio-resources like botanicals, cow urine individually and in combination and edible wax against white rot of apple in India to reduce the post-harvest losses caused by Botryosphaeria dothidea. Thus, there is a need for the development of alternative disease control materials that are effective in plant disease control and at the same time environmentally friendly.

\section{MATERIALS AND METHODS}

Periodic surveys were carried out at 20 days interval in different apple growing areas in the state of Himachal Pradesh, India. Incidence of post-harvest losses in apple due to white rot and different post-harvest pathogens was recorded in major apple marketing yard locally called "Mandis" in Narkanda, Shimla, Solan and Parwanoo during the season (June-November). The study to record the incidence was based on visual symptoms of the disease which were later confirmed by the isolation of fungus from the representative sam- ples of the diseased fruit. During the survey, white rot infected fruits were collected from these areas and were kept in polythene bags and brought to the laboratory for the isolation and confirmation of associated pathogen. Data was recorded by opening the packed fruit boxes as well as from the open heaps. Apple fruits showing white rot ( $B$. dothidea) symptoms were counted and percent disease incidence was calculated.

Isolation of the pathogen: Isolation of the pathogen involved in the rot were made from diseased portion of fruit samples of apple collected from different marketing yards of Himachal Pradesh. The diseased fruits were initially surface sterilised with absolute alcohol under aseptic conditions. Small bits of 1 to $2 \mathrm{~mm}$ size were taken from juncture of diseased and healthy part of fruit with the help of sterilised sharp blade or scalpel. These bits were surface sterilised with mercuric chloride $(0.1 \%)$ for 10 to 20 seconds and washed thrice with sterilised distilled water under aseptic conditions. The bits were then placed on the sterilised filter paper to remove the excess moisture and subsequently transferred to sterilised Petri plates containing potato dextrose agar (PDA) medium. The medium was supplemented with streptocycline (100 ppm) while pouring in Petri plates after sterilisation to restrict the bacterial contaminates. The inoculated Petri plates were incubated at $25 \pm 1^{\circ} \mathrm{C}$ in BOD incubator and examined daily for mycelial growth. The fungal growth developed in Petri plates was further purified by hyphal tip technique and was cultured on slants containing PDA. Pure culture was obtained by sub-culturing three times and maintained on culture slants in the refrigerator until required.

The morphological characters of the isolated fungus were similar to the published description of the fungus given in "Compendium of Apple and Pear Diseases" written by Sutton (1990). Thus, the description indicated the presence of Botryosphaeria dothidea. Also, the pure culture of this particular pathogen got identified through National Centre of Fungal Taxonomy, New Delhi under Id. No. 5217.12, which identified it as $B$. dothidea.

The pathogenicity test of the causal organism ( $B$. dothidea) was conducted by following Koch's postulates under in vitro conditions by inoculating the healthy fruits (Golden Delicious) apple through pinprick method (Wadia et al., 1983; Freeman et al., 1996; Jadesha et al., 2012). The inoculated portion of fruit was covered with sterilised paraffin wax and incubated at room temperature $\left(25 \pm 1^{0} \mathrm{C}\right)$. After inoculation, the fruits were immediately covered with sterilised filter paper and moist cotton to maintain the relative humidity ranged between 80-85 Percent.

Six effective plants were selected for making two botanical formulations. Those effective plants were Roylea elegans Wall., Artemisia roxburghiana Wall., Azadirachta indica L., Vitex negundo Linn., Ocimum 
sanctum L. and seeds of Melia azedarach L.. In Botanical formulation (BF1), equal quantity (200 g) of sixty days old freshly harvested leaves of Roylea elegans Wall, Artemisia roxburghiana Wall., Azadirachta indica L., Vitex negundo Linn., Ocimum sanctum L. and $200 \mathrm{~g}$ of mature seeds of Melia azedarach L. were taken. These leaves and seeds were washed in the running tap water and then with distilled water. Then, the paste of all these ingredients was made in a mixer and grinder. Then, equal quantity of distilled water $(200 \times$ $6=1200 \mathrm{ml}$ ) was added to this paste of leaves and seeds on weight and volume basis (w/v). Similarly, Botanical Formulation 2 comprised of all effective plant extracts which were used in preparation of Botanical Formulation 1.Then the paste of all these ingredients was made in mixer grinder by adding little quantity of fresh cow urine of Jersey cow. The cow urine has antifungal activities and inhibitory activity against many fungi. Cow urine is one of the ingredients of "Panchgavya" which is capable of treating many diseases as it has several medicinal properties and it is the best remedy to cure fungal and bacterial diseases. It has an excellent germicidal power, antibiotics and antimicrobial activity. Cow urine in combination with plant extracts is used to prepare disinfectant which is biodegradable and ecofriendly with good antibacterial action. (Dharma et al.,2005); Pathak and Kumar,2003; Mandavgane et al, 2005).Then equal quantity of cow urine $(200 \times 6=1200 \mathrm{ml})$ was added to this paste of leaves and seeds of six plants on weight and volume basis $(\mathrm{w} / \mathrm{v})$. Thus, while BF1 is water based formulation, BF2 is cow urine based formulation. These formulations were sterilised at $1.05 \mathrm{~kg} / \mathrm{cm}^{2}$ for 5 minutes (Tyndallization) and were evaluated against the white rot pathogen in comparison with effective fungicide (Score) for their mycelium inhibiting properties of the white rot pathogen.

Varietal behavior: Varietal behavior was also observed on four commercial varieties for their comparative susceptibility to white rot (B. dothidea). Apple fruit cultivars viz. Golden Delicious, Granny Smith, Rich a Red and Royal Delicious were examined for their comparative susceptibility. In different experiments, ten healthy fruits of each variety were inoculated by pin-prick method (Freeman et al., 1996; Jadesha et al., 2012). In this method, four sterile insect mounting pins of $(0.45 \mathrm{~mm})$ diameter were taken for inoculating the fruits with the spore suspension of conidia. Spore suspension of conidia was prepared by taking 20 days old vigorously growing culture of the fungus in Petri plates. Sterilized distilled water $(1.5 \mathrm{ml})$ was added to this culture to make the spore suspension $\left(10^{5} /\right.$ $\mathrm{ml}$ ). Then the sterilized pins were dipped in the conidial suspension and the fruits were inoculated on the side by piercing the skin of the fruits up to $1 \mathrm{~mm}$ depth. Then, the inoculated fruits were further subjected to different treatments in the management studies. All the inoculated fruits were kept at room temperature $(25 \pm$ $3^{0} \mathrm{C}$ ) for comparison. Percent rot was calculated in four different varieties after 10, 20 and 30 days of inoculation.

Efficacy of botanical formulations in different treatments: Six effective botanicals which inhibited maximum radial growth of the test pathogen under in vitro conditions were combined and evaluated in two combinations of Botanical Formulations 1 (BF1) and Botanical Formulations 2 (BF2) against the white rot incidence on fruits in storage (Fig.2). Freshly harvested fruits of Golden Delicious variety were procured from the market and these fruits were spread out on the working table of the laboratory so that fruits of uniform shape, size and maturity were selected. These fruits were sorted out to discard any immature, overripe, bruised undersized or diseased fruit. In each treatment, 35 fruits of uniform size were selected randomly. The efficacy of Botanical Formulations (BF1 and BF2) was compared with other treatments of fungicide and wax as fruit dip, dip of fruit wrappers and dip of fruit trays. Skin coating of fruits in BF1 and BF2 was done by dipping the fruits in different treatment solutions for 30 minutes. Fruits were dried after the treatment in the laboratory by spreading on working tables before packing in the trays. Fruit wrappers and trays were impregnated with botanical formulations and the test fungicide treatment for the protection of apple fruits (Fig.3). To prepare the impregnated wrappers of BF1 and BF2 formulations, five sheets of newspaper $(52 \times 33 \mathrm{~cm})$ were taken. These sheets were slowly poured with the solution (150 to $200 \mathrm{ml}$ ) of the desired treatment in a way so that the sheets (wrappers) were drenched with the solution without any spill out from the sheet. Uniform soaking of solution of each treatment was secured by spreading the solution slowly and smoothly over the sheets. The newspaper sheets were air dried in shade and sheets were then cut and divided in to wraps of uniform size measuring $25 \mathrm{~cm}^{2}$ in dimension. Similarly, fruit trays were also impregnated by dipping of these trays in different treatment solutions (BF1 and BF2) for 30 minutes (Fig.4). Trays were air dried after the treatment under shade in the laboratory before packing the fruits in the trays. Sterilized distilled water was taken as control for skin coating of fruits. Observations on efficacy of these treatments against white rot were recorded after 10, 20 and 30 days in storage at $25 \pm 3{ }^{\circ} \mathrm{C}$. Observations were taken with respect to incidence and lesion size of white rot in fruits was calculated by the following formula:

$$
\text { Rotting }(\%)=\frac{\mathrm{C}-\mathrm{T}}{\mathrm{C}} \times 10
$$

Where $\mathrm{C}$ is the control treatment where apples were not treated, $\mathrm{T}$ is the different treatments given to the fruits.

Application of chemical fungicide in different treatments: Most effective fungicide (Score $100 \mathrm{ppm}$ ) was 
Table 1.Incidence of post-harvest rots in apple from 2011 to 2013.

\begin{tabular}{|c|c|c|c|c|c|c|c|c|c|}
\hline \multirow{3}{*}{ Districts } & \multirow{3}{*}{$\begin{array}{l}\text { Terminal } \\
\text { Fruit } \\
\text { markets }\end{array}$} & \multicolumn{8}{|c|}{ Incidence (\%) of post-harvest rots in apple from 2011 to 2013} \\
\hline & & \multicolumn{2}{|l|}{2011} & \multicolumn{2}{|l|}{2012} & \multicolumn{2}{|l|}{2013} & \multicolumn{2}{|l|}{ Mean } \\
\hline & & White Rot & Other rot & White rot & Other rot & White rot & Other rot & White rot & Other rot \\
\hline & Narkanda & 2.5 & 11.2 & 3.5 & 13.6 & 3.0 & 15.3 & 3.0 & 13.4 \\
\hline \multirow[t]{2}{*}{ Shimla } & Shimla & 4.0 & 15.3 & 6.0 & 17.2 & 5.5 & 18.3 & 5.2 & 16.9 \\
\hline & Solan & 9.0 & 19.8 & 10.5 & 21.3 & 9.5 & 20.4 & 9.7 & 20.5 \\
\hline Solan & Parwanoo & 12.5 & 23.9 & 15.5 & 25.1 & 14.5 & 24.6 & 14.1 & 24.5 \\
\hline
\end{tabular}

Table 2.Susceptibility of different apple cultivars to white $\operatorname{rot}(B$. dothidea).

\begin{tabular}{lllll}
\hline \multirow{2}{*}{ Varieties } & \multicolumn{4}{l}{$\begin{array}{l}\text { Incidence (\%) of fruit rot after dif- } \\
\text { ferent durations (days) in storage }\end{array}$} \\
\cline { 2 - 5 } & $\mathbf{1 0}$ & $\mathbf{2 0}$ & $\mathbf{3 0}$ & Mean \\
\hline Golden Delicious & 21.75 & 77.60 & 100.00 & 66.45 \\
Rich-a-Red & 4.12 & 39.95 & 100.00 & 47.69 \\
Royal Delicious & 2.0 & 5.10 & 15.71 & 7.60 \\
Granny Smith & 0.00 & 0.00 & 0.00 & $\mathbf{0 . 0 0}$ \\
Mean & 6.97 & 30.66 & 53.92 & \\
\hline
\end{tabular}

mixed in distilled water in desirable concentration $(0.1$ $\mathrm{mg}$ ) and final volume (1 liter) of chemical solution was made. Fungicide was evaluated as fruit dip. Also, wrappers and fruit trays were also impregnated with the fungicide by dipping these in this fungicide. Skin coating of fruits in fungicide was done by dipping the fruits in fungicide solutions for 30 minutes. Fruits were then dried after the treatment by spreading them on the table before packing in the trays. To prepare the impregnated wrappers with the desired concentration of fungicide solution, five sheets of newspaper $(52 \times 33$ $\mathrm{cm})$ were poured with the desired fungicidal solution (150 to $200 \mathrm{ml}$ ) so that newspaper sheets were drenched with the solution and that solution do not spill out from set of five sheets. Uniform soaking of solution was secured by spreading the solution slowly over the sheets. The newspaper sheets were then air dried in shade and sheets were divided in to fruit wraps of uniform size measuring $25 \mathrm{~cm}^{2}$ in dimension. Similarly, impregnation of fruit trays was done with fungicide solution by dipping them for 30 minutes. Trays were then dried after the treatment in laboratory before packing the fruits in these impregnated trays. Sterilized distilled water was taken as control for skin coating of fruits. Observation on efficacy of these treatments against incidence of white rot was recorded after 10, 20 and 30 days in storage at room temperature $\left(25 \pm 3{ }^{0} \mathrm{C}\right)$. Observations were also taken with respect to lesion size of white rot in fruits was calculated by the following formula as given in equation (1).

Application of edible wax: Skin coating of fruits with edible Carnauba wax was done by dipping fruits in gently heated $\left(40^{\circ} \mathrm{C}\right)$ edible wax for 3-5 minutes. Then, the treated fruits were allowed to dry under shade so that edible wax cover whole fruit skin surface. Efficacy of this treatment was observed against fruit rot and quality of fruits after 10,20 and 30 days in storage at room temperature $\left(25 \pm 3^{\circ} \mathrm{C}\right)$. Observations were recorded concerning incidence of white rot in fruits, lesion size of the rot on fruits. In control treatment, no treatment was given to the inoculated apples. Each treatment was replicated thrice and each treatment had 45 fruits.

Statistical analysis: The data recorded from various in vitro and laboratory experiments were subjected to statistical analysis. The differences exhibited by treatments in various experiments were tested for their significance at 5 percent using standard procedure as described by Gomez and Gomez (1983).

\section{RESULTS AND DISCUSSION}

In the present study, survey of the important marketing yards in Shimla and Solan districts of Himachal Pradesh was conducted during the peak harvesting season

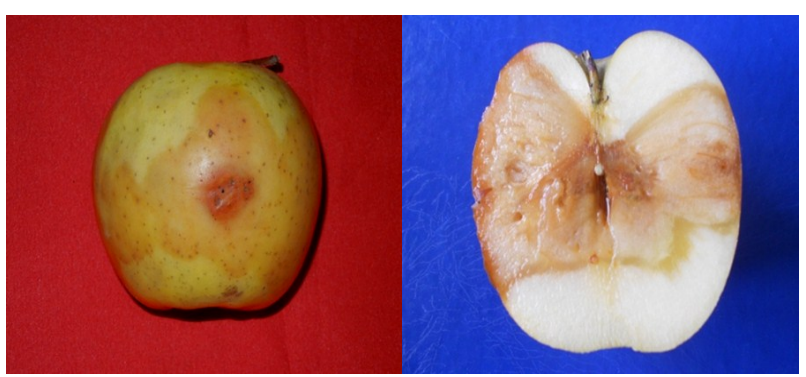

Fig.1. External and Internal symptoms of white rot of apple.

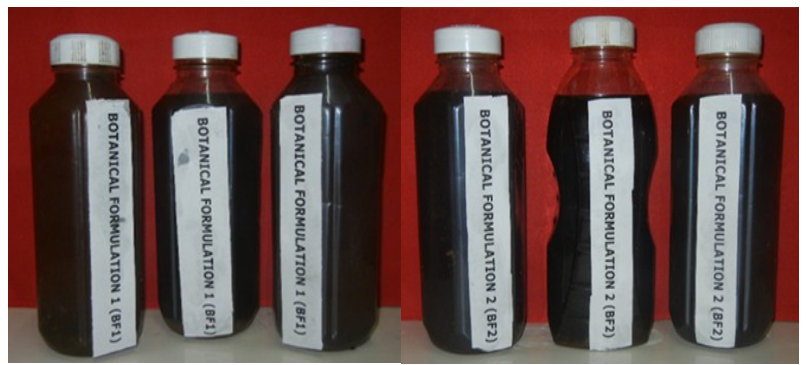

Fig.2. Botanical Formulation 1 (water based) and 2 (Cow urine based)

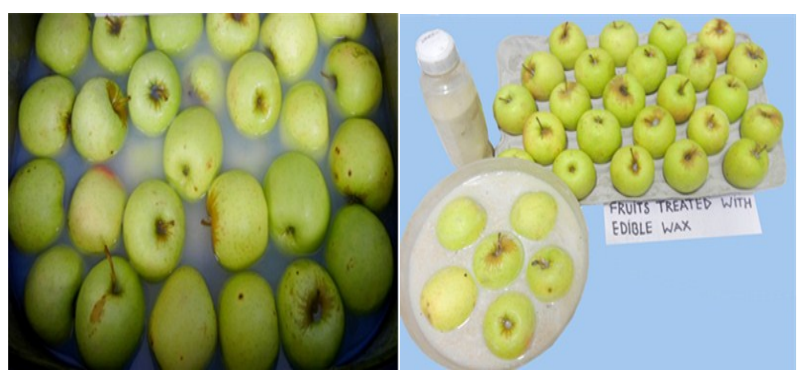

Fig.3. Fruits treated with score fungicide and edible camauba wax. 
Kishor Sharma and Harender Raj / J. Appl. \& Nat. Sci. 10 (1): 491 - 499 (2018)

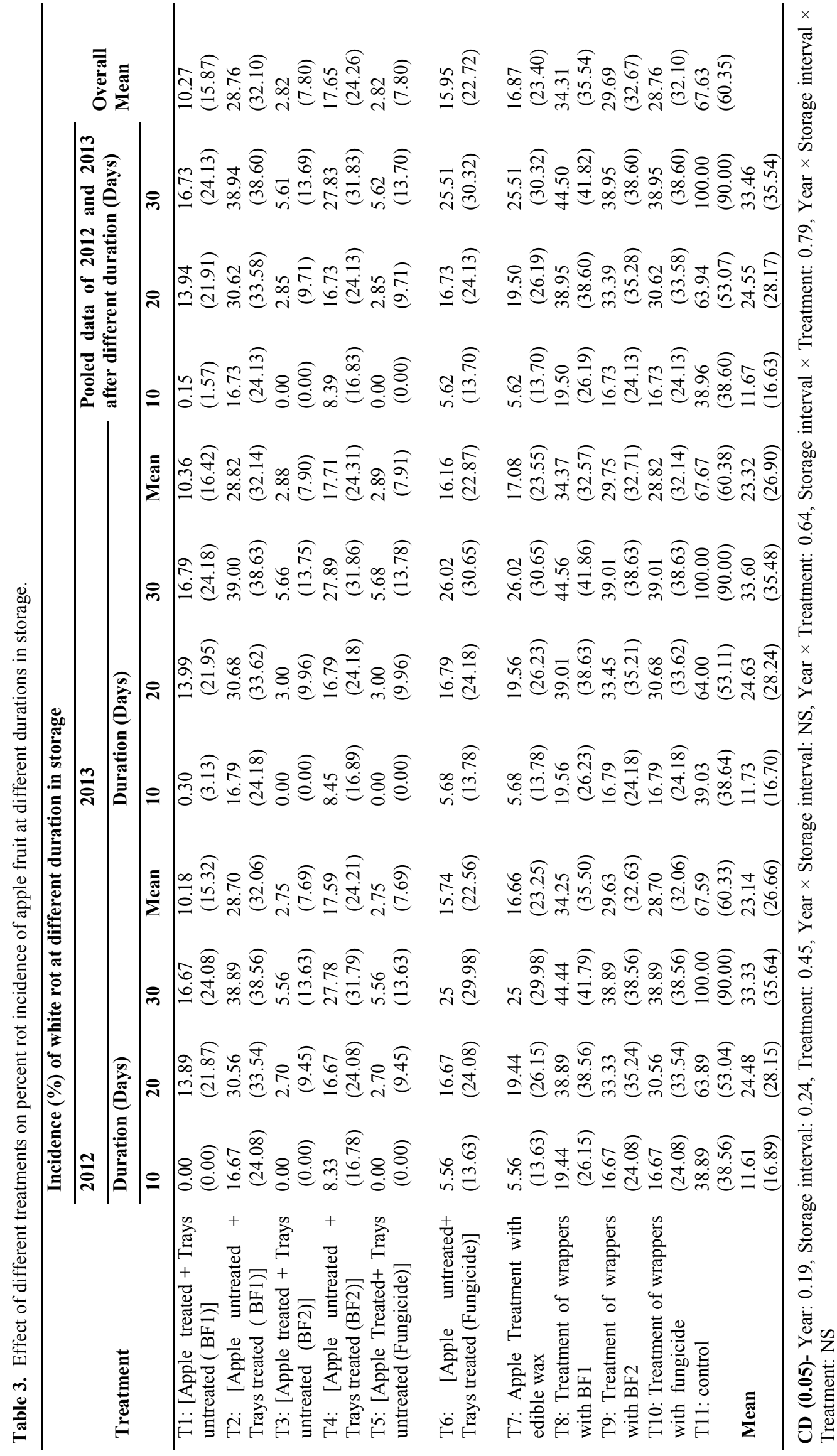




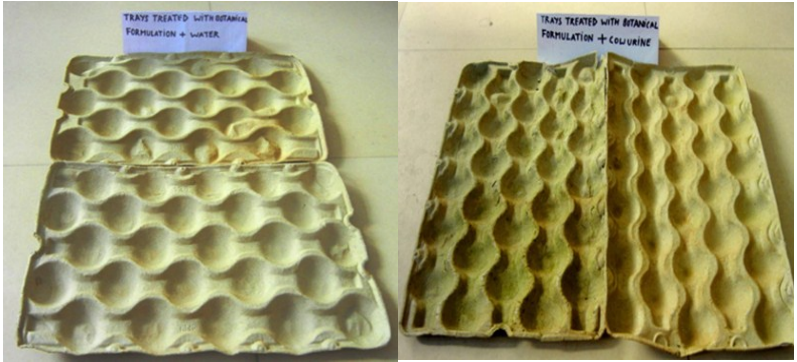

Fig.4. Trays impregnated with $B F 1$ and $B F 2$.

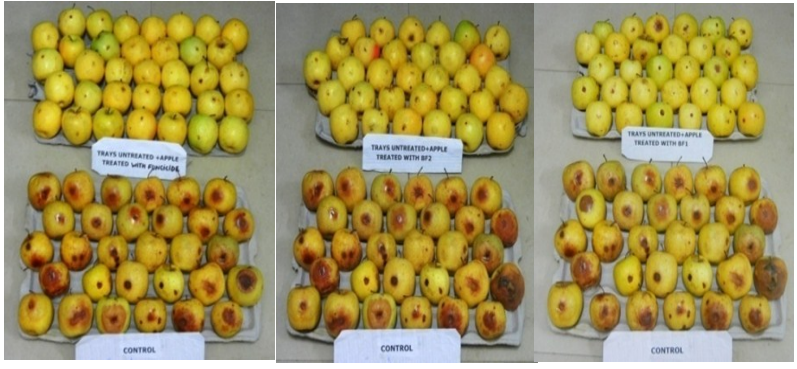

Botanical formulation -1 treated, Botanical formulation -2 treated, Fungicide (Score) treated

Fig. 5. Effect of different treatments on per cent rot incidence of apple fruit in storage.

of apple to record the incidence of white rot (Botryosphaeria dothidea) and other rots. Average incidence of white rot during 2011 to 2013 was more severe in marketing yards at Parwanoo(14.1\%) and Solan $(9.7 \%)$ which are located at lower elevations with warm climate in comparison to marketing yards at Narkanda (3.0\%) and Shimla (5.2\%)(Table 1). Similarly, incidence of other rot was recorded also higher at Parwanoo $(24.5 \%)$ and Solan $(20.5 \%)$ in comparison to incidence at Narkanda (13.4\%) and Shimla (16.9\%).In last few years, Khan et al. (2010) observed the incidence of white rot of apple in serious proportion from Jammu and Kashmir. Sutton (1990) found 50percent post-harvest loss in apple fruit was due to infection of white rot in warm and humid areas of South-Eastern United States. The initial symptoms were typically comprised of slightly sunken brown spots which were bordered by one or more red halo rings. As the decayed area expanded, the core became rotten in cylindrical manner (Fig.1). Behavior of four commercial cultivars of apple to inoculation of the white rot pathogen indicated that Granny Smith was less susceptible to white rot ( $B$. dothidea), which had no rotting of fruits even after 30 days. Many biochemical factors impact the resistance of Granny Smith apple to post-harvest decay like high-acid content, presence of glycoprotein endopolygalacturonase inhibitors, benzoic acid, $\mathrm{H}_{2} \mathrm{O}_{2}$ and its as well as peroxidase activity. In Granny Smith epidermal cortical tissue layer is hard and not easily broken by pathogen attack, resulting in less decay (Brown, 1984, Torres et al., 2003, Spotts et al., 1999).While, Golden Delicious cultivar was the most susceptible as it accounted for 66.4 per-

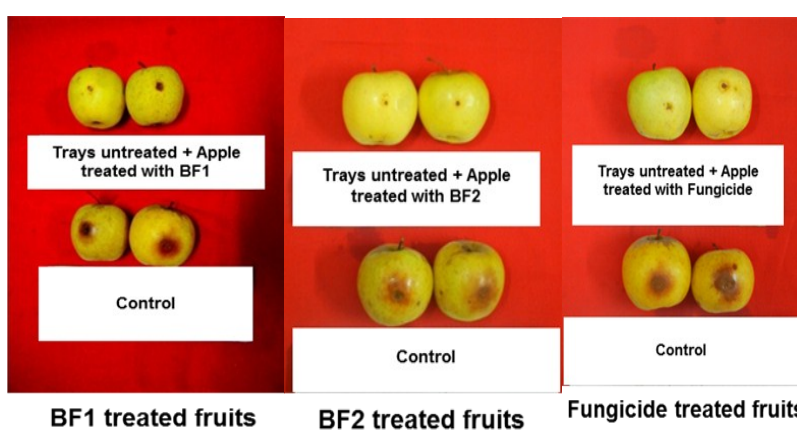

Fig.6. Effect of different treatments on lesion size of white rot.

cent overall rotting followed by Rich-a-Red which had 47.6 overall percent fruit rot (Table2). While, Royal Delicious cultivar of apple was less susceptible to the white rot with 7.6 percent of overall fruit rot incidence after 30 days of inoculation. In the present study, Golden Delicious was found the most susceptible cultivar followed by Rich-a-Red. In other studies, Golden Delicious has been reported as most susceptible cultivar of apple to white rot disease (McVay et al., 1993 and Biggs and Miller, 2003)

Eleven treatments were applied to the apple fruits and the fruits were stored at the room temperature $\left(25 \pm 3^{\circ} \mathrm{C}\right)$. The observations were recorded at 10,20 and 30 days interval. The data of two years indicate that the no white rot incidence was recorded in treatments T3 and T5 after ten days of storage as compared to control fruits where the rot incidence was 38.9 percent (Table3). Minimum average white rot incidence was recorded in treatments T3 (5.6\%) and T5 (5.6\%), after 30 days of storage. Fruit treated with BF1 (T1) had 16.7 percent incidence of white rot in comparison to 100 percent rot incidence in control fruits after 30 days of storage. Overall data of two years indicated that minimum incidence $(2.82 \%)$ was recorded in treatment T3 and T5. It was followed by treatment T1 with 10.27 percent incidence of rot. Incidence of white rot was maximum $(67.63 \%)$ in control (sterilised water treated) fruits. Raj and Tomar (2013) also reported effectiveness of fruit dip in botanical formulation with cow urine in reducing disease incidence of post-harvest rots of apples in storage (Fig.5). Effectiveness of cow urine based bio-formulation consisting of leaf extract of Bougainvillea glabra, Ocimum sanctum, Artemisia roxburghiana, Roylea elegans, Cryptolepsis buchanani and seed extract of Melia azedarach was also observed against grey mould incidence in strawberry (Raj and Sharma, 2013).Montealegre et al (2010) observed that use of chitosan and grape fruit extract in apple reduced incidence of grey rot (B. cinerea) when used as postharvest treatments under controlled condition. Different treatments i.e. direct treatment of apple fruits or impregnation of the packing material (trays or wrappers) has a different impact on disease development. 
Kishor Sharma and Harender Raj / J. Appl. \& Nat. Sci. 10 (1): 491 - 499 (2018)

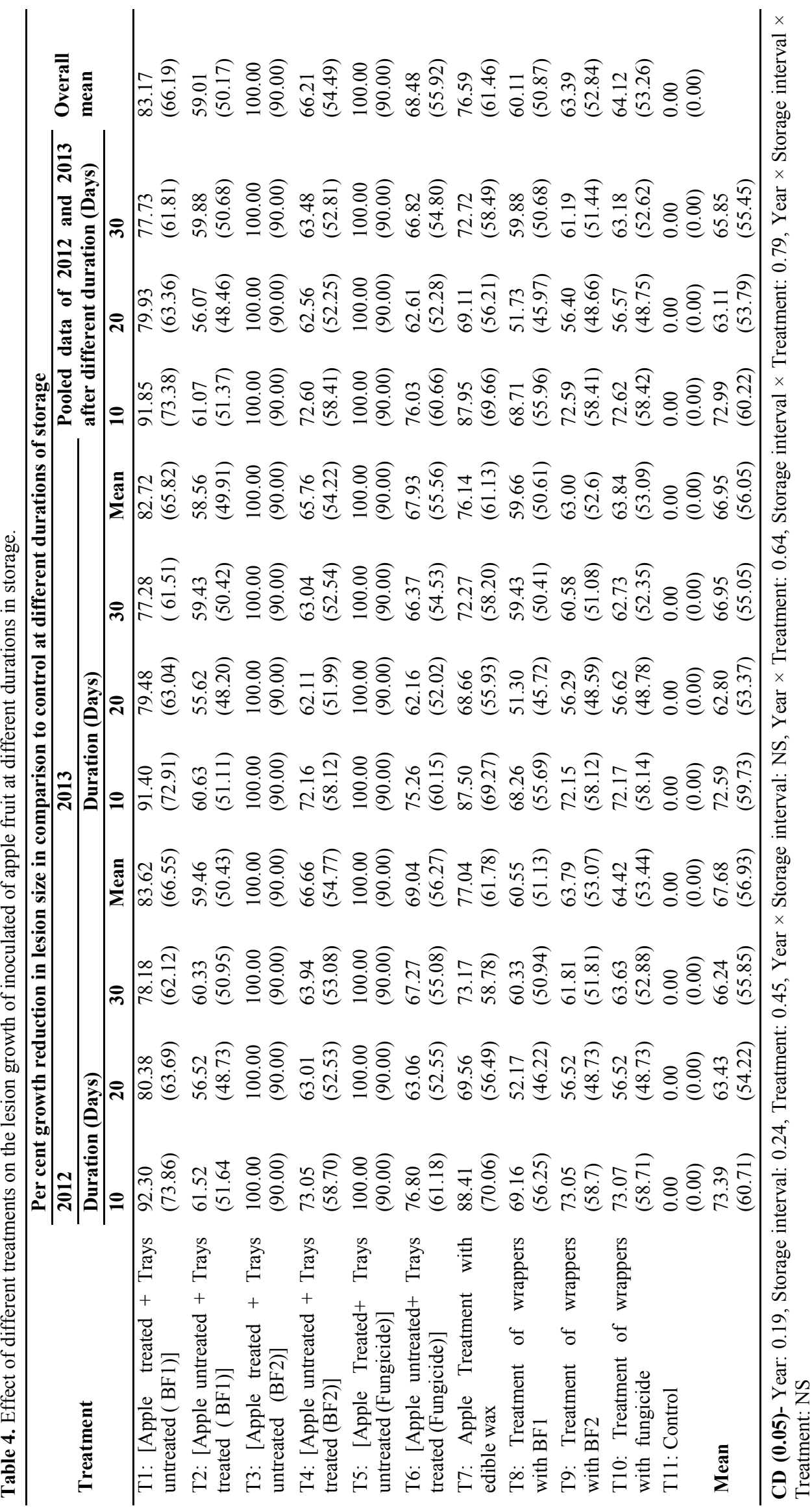


Hence, the progress of the inoculated lesion was also observed in different treatments to study the efficacy in restricting the growth of the inoculated lesion on the fruits. Pooled average of the two years data indicate that maximum restriction in lesion size $(100 \%)$ in comparison to control was found in treatments $\mathrm{T} 3$ and T5 after 10, 20 and 30 days of storage (Table 4), in which fruits were treated with BF2 and fungicide (Score), respectively. In the present study, treatment of apple fruits with Score and BF2 completely restricted the lesion size $(100 \%)$ during storage. Trays impregnated with BF2 also restricted the lesion size by 63.5 percent. Botanical Formulation 1 (BF1) was found less effective than BF2. Fruit dip of fruits and packing of fruits in trays impregnated with BF1 resulted in 77.7 and 59.9 percent restriction of lesion size in comparison to control, respectively after 30 days. However, application of plant extracts restricted the lesion growth of Penicillium expansum on apple fruits (Ikeura et al., 2011). Wang et al (2010) observed that treatment of fruits with neem seed kernel extract significantly reduced lesion diameter on plum fruits inoculated with Monilinia fructicola. Cosoveanu et al (2013) evaluated efficacy of Artemisia spp. extract against Penicillium expansum and reported that growth of lesion size get restricted by 88.5 percent after 17 days of inoculation on fruit.

\section{Conclusion}

White rot is emerging as an important post-harvest pathogen of apple in Himachal Pradesh with incidence ranging from 2.5 to 15.5 percent. Water and cow urine based botanical formulations made of leaves/seeds of six plants were found effective as fruit dip and also as impregnated on material in fruit wrappers and trays in reducing the incidence of white rot in storage. Treatment of fruit dip and impregnation of trays in cow urine based botanical formulation (BF2) was found equally effective with that of the treatment in fungicide (Score) with white rot incidence of 5.5 and 27.7 percent, respectively after 30 days of storage in comparison to 100 percent rotting in control. Most of plant parts used for extracts preparation of cowurine and water based botanical formulations are naturally available in abundance. Thus, botanical formulations of effective anti-fungal plants can be cost-effective alternative to fungicides for their use in the management of white rot in apple.

\section{ACKNOWLEDGEMENTS}

The authors are thankful to Head, Department of Plant Pathology, Dr. Y. S. Parmar University of Horticulture and Forestry, Nauni, Solan-173230 (HP) for providing necessary facilities during the experiment and Dr P N Chowdhry, Principal Mycologist National centre of
Fungal Taxonomy (NCFT), New Delhi for their valuable assistance regarding identification of the pathogen.

\section{REFERENCES}

Anderson, W. H. (1956). Diseases of fruit crops. Mc Graw Hill Book Company, New York p. 501

Anonymous, (2013). Crop production statistics. Food and Agriculture Organization of United Nations, Rome.

Biggs, A. R. and Miller, S. S.(2003). Relative susceptibility of selected apple cultivars to Botryosphaeria dothidea. HortScience 38 (3): 400-403

Brown, A. E. (1984). Relationship of endopolygalacturonase inhibitor to the rate of fungal rot development in apple fruits. Phytopathol. Z., 111: 122-132

Cosoveanu, A., Cabrera, R., Marino, C. G., Iacomi, B. M.and Coloma, A. G. (2013). Antifungal activity of plant extracts against pre and postharvest pathogens. Scientific Papers. Series A. Agronomy, Vol. LVI: 206-211

Dharma, K.,Rajesh, R., Chauhan, R. S. and Simmi, T. (2005). Panchgavya (Cowpathy): an overview," International Journal of Cow Science, 1(1):1-15

Eckert, J.W. and Ogawa, J. M. (1988). The chemical control of postharvest diseases: deciduous fruit, berries, vegetables and root tuber crops. Annu Rev Phytopathol 26: 433-446

Freeman, S., Katan, T. and Shabi, E. (1996). Differentiation between Colletotrichum gloeosporiodes from avocado and almond using molecular and pathogenicity tests. Appl. Environ. Microbiol. 62: 1014-1020

Fulkerson, J. F. (1960).Botryosphaeria ribis and its relation to rot of apple. Phytopathology 50: 394-398

Gomez, K. A.and Gomez, A. A. (1983). Statistical Procedures for Agricultural Research. $2^{\text {nd }}$ edition. John Willey and Sons Inc, New York, USA. p.680

Ikeura, H., Somsak, N., Kobayashi, F., Kanlayanarat, S.and Hayata, Y.(2011). Application of selected plant extracts to inhibit growth of Penicillium expansum on apple fruits. Plant Pathol. J.10: 79-84

Ilyas, M. B., Ghazanfar, M. U., Khan, M. A., Khan, C. A. and Bhatti, M. A.R. (2007). Post-harvest losses in apple and banana during transport and storage. Pak J Agri Sci 44(3): 534-539

Ivic D, Server Z. and Milicevic T. (2012). Estimation of economic loss due to postharvest diseases of apple (cv. Idared) during four seasons.Pomologia Croatica 18:1-4

Jadesha, G., Haller, H., Mondhe, M. K., Hubballi, M., Prabakar, K and Prakasam, V.(2012). Application of plant extracts induced the changes in biochemical composition of banana fruits. Ann Biol Res 3 (11): 51335140

Jijakli, M. H., and Lepoivre, P. (2004). State of the art and challenges of post-harvest disease management in apples. Fruit and Vegetable Diseases-Volume 1, Mukerji K G ed. Kluwer Academic Publishers, Dordrecht, Netherlands, pp: 59-94

Kasso, M. and Bekele,A. (2016). Post-harvest loss and quality deterioration of horticultural crops in Dire Dawa Region, Ethiopia.Journal of the Saudi Society of Agricultural Sciences.1-9

Kaul, J. L. (1979). Studies on important postharvest diseases of apple caused by fungi and their control, Ph.D. Thesis, Himachal Pradesh Krishi Vishva Vidyalaya, Solan (HP), 
India p. 214

Khan, N. A., Ahmad, M. and Ghani, M. Y. (2010).Botryosphaeria dothidea associated with white rot and stem bark canker of apple in Jammu and Kashmir. Appl. Biol. Res 12(2): 69-63

Mandavgane, S. A., Rambhal, A. K. and Mude, N. K. (2005). Development of cow urine based disinfectant," Natural Product Radiance, (4): 410-412

McCollum, T. G. (2002). Molecular biology of hostpathogen interactions in harvested horticultural crops. HortScience 37 (2): 456-458

McVay J. R., Walgenbach J. F., Sikora, E, J. and Sutton, T. B. (1993). A growers guide to apple insect and diseases in South-East. Alabama Cooperative Extension System. Auburn University Circle, p. 838

Montealegre, J. R., Lopez, C., Stadnik, M. J., Henriquez, J. L., Herrera, R., Polanco, R., Piero, R. M.and Perez L. M.(2010). Control of grey rot of apple fruits by biologically active natural products. Trop Plant Pathol 35(5): 271-276

Okigbo, R. N and Ogbomaya, V. O. (2006).Antifungal effects of two tropical plant leaf extracts (Ossimum gratissimum and Aframomum meleguata) on post-harvest yam (Diascorea spp.) rot. Afr. J. Biotechnol., 5: $727-731$

Onyeani, C. A., Osunlaja, S. O., Oworu, O. O. and Joda, A. O. (2012). Evaluation of effect of aqueous plant extract in the control of storage fungi. IJRST 1(6): 76-79

Pathak,M. L and Kumar, A.(2003).Cow praising and importance of Panchyagavya as medicine. Sachitra Ayurveda, 5: 56-59.

Putterill, V. A. (1919). A new apple tree canker. S AFR J SCI 16: $258-271$
Raj, H. and Sharma, R. L.(2013). Bioefficacy of aqueousand cow urine based bioformulations against grey mould of strawberry. J Plant Pathol 43(3): 319-322

Raj, H. and Tomar, M. (2013). Use of aqueous and cow urine based plant extracts against post-harvest diseases of apple. J Plant Pathol43 (2): 246-249

Rosenberger, D.A. (1997). Recent research and changing options for controlling postharvest decays of apples. Proc. Harvesting, Handling and Storage Workshop. Northeast Reg. Agric. Eng. Serv. Publ. NRAES-112. Cornell University, Ithaca, NY

Spotts, R. A., Cervantes, L. A. and Mielke, E. A. (1999). Variability in postharvest decay among apple cultivars. Plant Dis., 83: 1051- 1054.

Sutton, T. B. (1990). White rot. In: Compendium of Apple and Pear Diseases. Jones A L, Aldwinckle H S eds., American Phytopathological Society, St. Paul, Minnesota pp. 16-18

Torres, R., Valentines, M. C., Usall, J., Vinas, I. and Larrigaudiere, C. (2003). Possible involvement of hydrogen peroxide in the development of resistance mechanisms in 'Golden Delicious' apple fruit. Postharvest Biol. Technol., 27: 235- 242.

Wadia, K. D. R., Manoharachary, C. and Janaki, C. H. (1983). Fruit surface mycoflora of Vitis vinifera L. and Capsicum annum L. in relation to their fruit rot diseases. Proceeding of Indian National Science Acadamy B46: 371-379

Wang, J., Li, J., Cao, Jand Jiang, W.(2010). Antifungal activities of neem (Azadirachta indica) seed kernel extracts on postharvest diseases in fruits. Afr. J. Microbiol. Res., 4 (11): 1100-1104 